\title{
Editorial
}

\section{Peter Sherlock}

University of Divinity and Editor, Journal of Anglican Studies

Email: petersherlock@divinity.edu.au

The global pandemic of 2020 has revealed many truths about the state of contemporary civilization. We know much more about the degree to which people do or do not trust their governments, health systems and economies. Societies have been placed into varying degrees of lockdown (or not locked down at all), people have been compelled or urged to change their behaviours, and evidence-based health advice has become pivotal to the success or failure of our social, cultural and political structures. Through all this, fundamental beliefs have become visible in new ways. Religion has been no exception to this. Public health orders around religion have focused primarily on religious ceremonies, on gathering for worship and for rites of passage. As adherents have had to find new ways to express their beliefs, translating liturgical or social action into online behaviours, believers have been forced to re-examine the fundamentals of their faith. What does it mean, for example, to love God or to love your neighbour when it is forbidden to gather with friends or strangers in one's own household? What does it mean to be Anglican in such a time?

The world revealed by the coronavirus is full of twists and turns, with previously hidden corners bringing both tragedy and hope into view. Much ink has been spilled, for example, over sacramental ministry, specifically eucharistic celebration and the reception of holy communion in communities excluded from assembly or from their customary places of worship. But there have been other ramifications, ones which may prove to be even more historically significant. Arguably the most distinctive and enduring ritual expression of Anglicanism is choral evensong. Singing, however, is particularly dangerous for a virus that is spread by airborne droplets. As a result even the most illustrious bastions of Anglican choral music have had to cease and desist for a time, while congregations of every kind of musical inclination have been prevented from creating that communion, that holy fellowship, of a different and vital kind: singing together.

Another of the strangenesses of these times has been a new twist in the relationship of the global and the local. On the one hand, this is a truly global pandemic, an event affecting all parts of the world and thus all parts of the Anglican Communion. Yet on the other, it has put a brake on international travel and seen the closure of borders in even the most progressive democratic nations. The Lambeth Conference has been postponed. The Communion's bishops meet in their provinces by videoconference, and adapt rituals such as confirmation or ordination to the rules of social distancing. As devastating as the pandemic has been, it has also brought a renewed focus on local community, on the immediate neighbourhood. Parishes 
and congregations meet online, not only for Sunday morning worship but for the daily office, for morning tea and for committee meetings, and anecdotal evidence suggests that in many of these cases attendance has actually increased. While sectors that rely on travel and association have been hit hard, such as hospitality, retail, tourism and education, local shopping strips have seen something of a renaissance of the local resident customer. Anglicans may have much to offer this situation, familiar as they are with the strengths and weaknesses of the English parochial system of organization and with the pros and cons of a global communion held together not by formal agreements but by shared beliefs, behaviours and histories.

In the midst of the crisis, writing about Anglicanism may seem like a luxury. Yet - as the articles in this issue of the Journal amply illustrate - there is much to be gained from training a critical eye on beliefs and behaviours, and rethinking who we are and how we act in response. The methodology of Anglican studies is a distinctive theological combination of biblical, liturgical, political, historical and spiritual studies. This is a response to a distinctively Anglican ideal of what it is to be human: what it means to exist in relationship to God, to each other, and to our past, present and future contexts. The mission of this Journal includes the presentation of as broad a range of perspectives and topics relating to Anglicanism as possible, in the belief that the extent to which we may discern of truth is proportional to the range of engagement with human diversity. Critical examination of this kind can produce surprising results pertinent not only to Anglicans but to the peculiar circumstances of humanity in 2020. Through the pages of this Journal, there is an opportunity to demonstrate not only the relevance of Anglican studies to the contemporary world, but the benefit such studies may bring to understanding how humans live together with a diverse range of creeds and customs, and how we make sense of it all.

Cite this article: Sherlock, P. (2020). Editorial. Journal of Anglican Studies 18, 127-128. https://doi.org/ $10.1017 / S 1740355320000509$ 